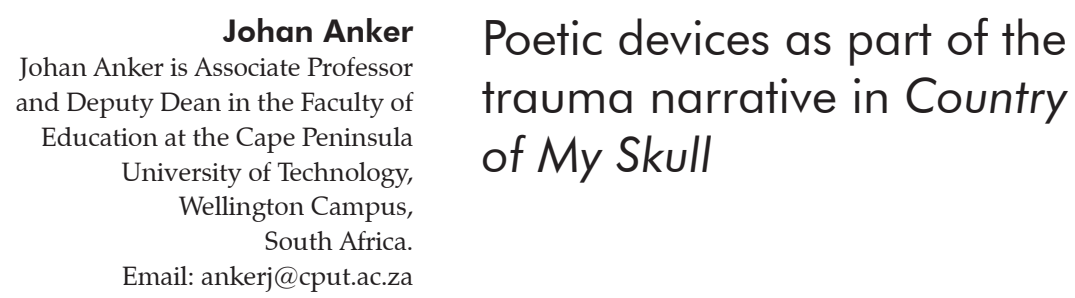

\title{
Poetic devices as part of the trauma nar- rative in Country of My Skull
}

This article investigates the role of poetic devices in a trauma narrative like Country of My Skull. The nature and characteristics of a trauma narrative are described with reference to Country of My Skull and Antije Krog's style as poet and journalist. The theory and role of figurative language in trauma narratives suggest an attempt to describe that which is indescribable and unrepresentable about traumatic events and experiences like Krog attempts to do in Country of My Skull. Different tropes like skull, language, body, sounds and landscape or country are identified and followed through the text as part of the working through of a traumatic experience. Krog is the narrator in this "highly personal account", describing the traumatic testimonies of witnesses during the South African Truth and Reconciliation Commission. She is confronted with her own traumatic experience as secondary witness to these events as a reporter, journalist, and translator-interpreter of stories of unspeakable horror. The broadening of perspective in the different tropes shows signs of the working through of this trauma and the process of healing to the reintegration of a divided, fragmented identity and agency. Keywords: Antije Krog; Country of My Skull; poetic devices; trauma narrative

\section{Introduction}

Country of My Skull (1998) is Antjie Krog's memoir about the years she spent covering South Africa's Truth and Reconciliation Commission for the South African Broadcasting Company. She narrates this experience in several registers, styles and genres: reportage, memoir, poetry, an invented affair, parliamentary dialogues, actual witness testimony, lyrical passages, personal experiences and conversations that develop between witnesses (Rostan; Speary; Moss).

The purpose of this article is to discuss the use and role of the various stylistic devices of fiction and poetry (like the different tropes identified) in Country of my Skull as an essential part of this trauma narrative. Although much has been written with regard to many aspects of this multi-layered text, not enough attention has been given to the functionality of the use of the different tropes and other stylistic devices.

Krog was criticized heavily for this hybrid text and for her use of the mixture of fact and fiction. Reviews and articles were negative about the way she formulated and presented the oral witnessing of the victims and witnesses of the atrocities of the apartheid regime as part of their evidence to the Truth and Reconciliation Committee. She was criticized for the idiosyncratic way in which she handled the 
available material and objections were especially made against the appropriation of victims' testimonies, the personal character of the text, the instability and variety of voices and narrators, the poetic style, the abundant use of overdrawn metaphors, the mixture of journalism and literature, fiction and non-fiction, the undermining of truth and the reference to a fictional affair (Graham; Harris; Cook; Walker and Unterhalter; Moss; Wallmach).

Contrary to the above, several articles, some of them very recent publications, like those of Marisa Botha in Tydskrif vir Geesteswetenskappe and a collection of essays on Krog's oeuvre, Antjie Krog: An Ethics of Body and Otherness (Coullie and Visagie) are very positive about Country of My Skull as an hybrid text including literary techniques (see Osinubi; Harris; Olivier; Speary; Walker and Unterhalter).The writers of these articles emphasize different aspects of the text as contributing to a formidable body of work. They discuss the use of the variety of narrators and voices as representative of the great number of victims and witnesses, the importance of the role of the secondary witness, the struggle of the narrator with the forming of a new identity and the empathy with all the other voices in this country. They also refer to the metaphors of a new dispensation after apartheid and the role of the use of metaphors and other stylistic devices of fiction and poetry in a narrative of working through trauma. The untenable situation of Krog as broadcaster, translator, narrator and witness who also had to fulfil the role of author is emphasized.

The text of Country of My Skull refers directly to the traumatic nature of testimonies and experiences. The book deals with extreme personal trauma through direct quotations of testimonies during the hearings. There is also secondary trauma experienced through the memories of these events, associative trauma to those listening as secondary witnesses and the experience of these testimonies, hearings and memories by reporters and translators. The emphasis of the article will be on Krog's own experience as secondary witness in the different roles she had to play.

Krog herself spoke specifically on the nature of Country of My Skull as a description of an extreme personal experience of the workings of the Truth Commission ("Last Time" 1). Susan Speary (9) also refers to the process of working through trauma as one of the basic structuring principles of this text: "A concern with trauma is insistently and explicitly foregrounded in the text, as Krog presents us with a nation and hundreds of individuals in the process of trying to incorporate stories that are so devastating that they threaten to disintegrate existing understandings of selfhood, both individual and collective, entirely. Arguably, Krog's working through of her own trauma of witnessing and of implication becomes the book's central structuring principle". Speary $(6,7)$ gives attention to the characteristics of trauma, the process of working through trauma and the influence it has on the ability to narrate the trauma of victims and witnesses alike. The writing of fragmentary texts is emphasized by the style of the "report"; not only as a form to mirror the traumatic content, but also as 
a different means of trying to narrate the incomprehensible and working through of the traumatic event. Speary (1) also refers to the "overtly fictionalised and poetic explorations of working through trauma" in Country of My Skull and Moss (86) refers to the "intensity of [Krog's] depiction of the pain of the Afrikaner-reporter".

Krog ("Last time" 1) describes Country of My Skull as "my own, highly personalized version of experiences at the Truth Commission. "Country of my Skull is NOT a journalistic or factual report of the Truth Commission. In fact, the problem of truth, the ethical questions around the 'making' of truth [...] all form part of the text itself". She refers to the image of a quilt to describe the nature of the text: "a quilt of personal, South African and international input". She also refers to the Dutch description of Country of My Skull as "creative non-fiction" ("Last time" 1).

One of the techniques used to foreground the personal aspect and differing perspectives in her text is to make use of different narrators (Graham 18, 22; Harris 43 and Coetzee 686). Moss (89) refers to a "proliferation of voices" and also thinks that the four narrative I's "undermine historical witnessing" while Cook (81) refers to "textual aliases" and Antjie as a "floating signifier".

It is evident that the "Antjies" are in conflict and the use of multiple names is a way of creating different roles for the narrators in the text: a reporter remaining faithful to the truth, one who questions the truth and writes her own truth and one who deals poetically with the truth. These different narrators become part of a polyphonic text imagining the Truth Commission, creating the space for an open dialogue and different genres, including her own perspective (Moss 90). This is also part of the struggle with a fragmented self to find a new unified identity which is typical of trauma narrative.

\section{Trauma and a trauma narrative}

To discuss Country of My Skull not only as a "highly personalized version" of the Truth Commission ("Last time" 1), but also as a trauma narrative, it is necessary to look at the characteristics of trauma and a trauma narrative. According to Cathy Caruth (11) "trauma describes an overwhelming experience of sudden or catastrophic events in which the response to the event occurs in the often delayed, uncontrolled repetitive experience of hallucinations and other intrusive phenomena". Other researchers (Van der Kolk; Brevin; Peres et al; Williams; and Seeley), have pointed to a long list of characteristics and symptoms of Post-traumatic Stress Disorder (PTSD) that may be suffered after experiencing a traumatic event, which include difficulty in putting the experience into words, dissociation, anxiety, depression, numbing of emotions, detachment, fragmented memories and flashbacks, and feelings of betrayal and anger.

It is especially the loss of language, the inability to narrate the traumatic experiences and the witnessing of traumatic events that are emphasized in discussions of trauma in reference to Country of My Skull. Van der Merwe and Goboda-Madikezela 
(26) refer to the fact that finding words and formulating a narrative is a way of encoding trauma within the structure of language to bring order to the fragmented and splintered experience. Olivier (3) argues with reference to Lacan that "the register of the so-called 'real' announces itself precisely there where language comes up against its own limits". Olivier (4) further states that the inescapable need to narrate the traumatic event, to reconstruct it over and over again, forms the core of the struggle to work through trauma and comprehend some of it, precisely because it escapes the symbolic naming in language, and thus cannot be assimilated. This reconstruction through the medium of a symbolic, metaphoric domain is the only form and method with which to establish some truth, which in turn becomes a narrative establishment of the trauma, although unfinished and vague (Olivier 10).

The nature of descriptions of different aspects of trauma in Country of My Skull and the personal description and style of Krog result in a complex context for the reader. There is the PTSD that follows the event, the trauma that comes with the memory or recounting of the event and the secondary associative effect on those listening, reporting and interpreting. Then there is Krog giving voice to the testimonies and translating and interpreting the testimonies. She herself becomes traumatized as witness and reporter while also writing a narrative that may traumatize her readers.

In an article in the Mail \& Guardian ("Overwhelming trauma" 10), before Country of My Skull was published, Krog wrote about her struggle to find the words for describing the traumatic events and testimonies that she had to endure and report on. As in the text of Country of My Skull she refers to her own break-down and the warning of the psychologist that they, as secondary witnesses, would experience the same symptoms of PTSD as a result of their exposure to the testimonies. At a later stage she describes how the hearing of one testimony after another overcomes these journalists emotionally: "And it wipes us out. Like a fire or a flood" ("Overwhelming trauma" 10). She is losing hair, her teeth are falling out, she develops a rash and to broadcast these events leaves her without breath: "everything tears out of me. Flesh and blood can in the end only endure so much" ("Overwhelming trauma" 10).

Krog, after considering the role of poetry in representing South Africa's past, writes in Country of My Skull: "No poetry should come forth of this. May my hand fall off if I write this. If I write this, I exploit and betray. If I don't, I die" (49), and in the end she states: "I want this hand of mine to write it. For all voices, all victims" (278). While she questions her right to appropriate stories paid for with a lifetime of pain, she feels the stories must be told from the context of the Truth Commission testimonies to a wider audience, that she as secondary witness bears a responsibility to those who testified. She also needs to write in order to save her sanity; she must struggle through this narrative to regain her sense of identity and agency that has been fragmented by all the experiences, questions and feelings of guilt and complicity (Coullie 128, 129). 
In the text itself there are repeated references to the experience of trauma on different levels: direct quotations of testimonies, some with names attached, others not; the symptoms of PTSD, the experience as a secondary witness and theoretical reflections on the nature of trauma and narrative. References are made to her loss of and struggle with finding the right words and language, the need for the birth of a new language, images of devastation, emotional images of a landscape filled with traumatic memories, a bodily and sensory experience of these events, the struggle with a concept of the truth, the different stories that are told and poems about the traumatic experience. It thus becomes difficult not to read Country of My Skull as a narrative of trauma.

The form of the text itself also depicts the nature of trauma. Speary (9) characterizes the text as one that "draws attention to variations upon and associative effects of trauma". Krog finds a form ("imposes a structure") to narrate some of the traumatic events that she experienced and witnessed as reporter and translator. This includes characteristics of the text like the fragmentation of the text to mime the nature of trauma, the narrativisation, the fictionalisation, even "a radically overdetermined narrative" (Cook 79), the strategies for quilting victims' testimonies, the lyrical and poetic style and the open ending. It is during the integration of a personal narrative, social commentary, family history, Truth Commission testimony, imagined conversations and fragments of poetry in Country of My Skull that Krog forms her dialogue with and struggle to find a personal truth (Cook; Graham; Harris; and Walker and Unterhalter).

In the narrative of Country of My Skull the importance of the therapeutic use of the writing of poetry as a process of working through her trauma as secondary witness to the Truth Commission is part of the process of identity formation and construction as is, according to Botha, also conveyed in Krog's poetry in Kleur kom nooit alleen nie (2000), which was published after Country of My Skull. Botha also alludes to the close connection between trauma memory and the trauma narrative, especially when organized and constructed as a narrative (536).

The role of the emphatic listener and witness is of the utmost importance in Country of My Skull, especially with regard to the primary trauma suffered by the victims and the secondary trauma suffered by the audience, in this case including the reporter and narrator, Antjie Krog/Samuel. Graham (27) believes she "set out [...] to create a form in which victims can be allowed not only to 'speak for themselves' [...] but to do so in a way that creates or dramatizes the disjuncture and displacements of trauma". The text emphasizes the untenable position of the narrator-reportertranslator who has to listen to and witness traumatic stories, translate them in the first person and interpret them to a wider audience. Even the sound effects within the different hearings and the broadcasting by radio became sound effects that are, according to Osinubi, "tropes for representation of violence" (120) and as such become 
concrete metaphors of the pain that the narrator endures and witnesses. The stories that Krog, and the other translators, must endure are so shocking that the first narrative she has to report on already penetrates "even the most frigid earhole of stone" (56); what she hears is a reality that surpasses all fiction (42), "each syllable vibrates with a lifetime of sorrow" (102). This traumatic experience becomes so embodied that she closes her memoir with this plea: "We have to hear each other's scalp and smell, each other's blood and baled belonging. We have to learn the deepest sound of each other's kidneys at night" (293). It is important to keep in mind that before she wrote the book she was a radio reporter who tried to immerse her audience in the testimonies and values of the Truth Commission. The embodiment of all these experiences thus spreads over a long period.

Krog is looking to construct a text that must display her own role as bearing witness to testimonies of the national past. This entails includes finding a literary form for the traumatic events while listening to and then transposing the testimony into her own fiction. Krog's states that she does not understand why her semi-fictional text is being assessed as a "factual report" ("Last time" 1). As a writer she must combine memoir and reportage in describing the role of bearing witness to spoken testimonies, hearing the words spoken and the anger and anxiety of the speakers.

She is witnessing the personal trauma of the speaker, experiencing the words spoken and the emotions with which they are expressed beyond immediate questions about the very complicated or simple "truth" (Harris 30). These testimonies do not only have an emotional effect on the speakers but are also transferred to the body of the witness and listener, in this case also the reporter.

Krog is a "secondary witness" who is confronted with the language of testimony as she narrates and interprets the pain of others where the testimony of the primary witness breaks down. She narrates the unspeakable trauma and puts in place a trace of the trauma being narrated (Harris 35). The language of the text may be interpreted within this framework of primary and secondary witnessing. That is why Krog refers to the cry of Nomonde Calata at the beginning of the Truth Commission, as a "signature tune", "the ultimate sound" that will "haunt me forever" (42).

Initially as a witness, Krog experiences the same loss of language (she finds herself "without language", 48), but as she takes on the role of witness and interpreter of the unspeakable she becomes part of the birth of (her own) language in spite of the intense struggle with her mother tongue (Afrikaans) which, according to her, is a language which "carries violence as a voice"' (216). Krog writes about her change of perspective on the Truth Commissiom after Desmond Tutu's prayer that they as a commission may have the strength to "listen to the whispers of the abandoned, the pleas of those afraid, the anguish of those without hope" (22). The speechlessness begins to give way to a form of speech, a form of bearing witness when she begins her search for a language that could begin to describe the traumas of the past. This 
leads to a more personalised, individual voice in which she describes the witnessing of her individual truth and the traumatic past. It is at this stage, when she is able to integrate and translate these traumas into her own personal narrative, "represented by deeply personal narrative threads in the text [...] that she finds herself able to speak of these horrors, importantly, in her own language" (Harris 39). Krog writes in Country of My Skull: "Something opens and something falls into the quiet space. A tone, an image, a line mobilizes completely. I become myself" (36). The language that returns is in a different mode and style, that of the metaphoric and the poetic, and it is this metaphorical, literary style that becomes one of the crucial elements of this text.

\section{The role of metaphorical language in trauma}

Equally important is the role of metaphors and poetic style used to describe the indescribable and the unrepresentable but also the importance of finding a narrative to help with the processing of trauma which allows reconstruction of identity and agency. According to James Berger ("Trauma without disability" 566) "trauma signifies the collapse of signification and the narrative working through can lead to the constitution of a new symbolic order".

Berger ("Trauma" 563) goes on to state that "trauma theory is, in many ways, ultimately a theory of metaphor; it is a way of thinking about how some extreme event or experience that is radically non-linguistic, that seems even to negate language, is somehow carried across onto language ..."; in his mind "trauma is a metaphor generator" ("Trauma" 576) and it is the effects of the real trauma that "generates further symbolization in the effort to cover or deny the fissure" that follows after trauma (Berger, "Falling towers" 345).

Metaphors may be a reference to a traumatic experience, the memory of trauma and the healing process in working through trauma. Lakoff and Johnson had, in 1980 already, described the functions of metaphor and showed that metaphorical thought is normal and ubiquitous in our mental life, both conscious and unconscious (244). They continue to state that, "A great deal of everyday, conventional language is metaphorical, and the metaphorical meaning is given by conceptual metaphorical mappings that ultimately arise from correlations in our embodied experience" (247). In Country of My Skull not only metaphors, but the form of the text and literary stylistics are part of these "metaphorical mappings". A psychologist like Borbelly writes extensively about the working of metaphor during the experience of trauma.

Anker (51-2) refers to psychologists like Modell, Borbelly, and Wilkinson who agree about the role of metaphor. They formulate this role as that of facilitating the emergence of the traumatic memory. Metaphor has the power to re-establish the integrated working together of the two hemispheres of the brain after trauma. In the therapeutic process it is important to recognize that metaphors are believed to 
activate multiple brain centres simultaneously. In this case a speaker makes use of one linguistically articulated domain to gain understanding of another experimental or conceptual domain, by which a hearer may linguistically formulate an understanding of the event. The role and function of metaphor is to deal directly with the transformation and creation of new categories. Accordingly it functions as a structure that establishes a "mapping of knowledge from one domain to another' (Borbelly 926).

The argument is that trauma leads to a degradation of metaphorical processes to mere analogical ones which relate to the repetition compulsion. This establishment of metaphorical connections between the developmental events and transference events will lead to the re-establishment of creativity. During this process the conceptual categories within which past traumatic experiences were understood remained frozen, awaiting metaphorical enrichment through interpretation and insight (Borbelly 926). In this state trauma reduces the polysemy of images of experience due to overwhelming anxiety, and leads to a fixed meaning of experience. Schwager (375, 378) states that symbol formation and metaphor is one of the most important tools for trying to comprehend partially what cannot be comprehended totally. It is during this process that what is not known and feared is revealed gradually. Psychologists like Williams (330) and Kaminer (486) also emphasize the role of metaphor in the working through of trauma by referring to the creative process that is found "in the transformation of metaphor, symbols and patterns in words and visualizations".

Telling the story through new perspectives thus provides the opportunity to assign meaning, integrate the experience, find recognition and relive events. In my opinion this is precisely what Krog is doing in Country of my Skull, where she has to struggle with herself to get distance from the testimonies and horrors she is hearing and describing. Simultaneously she questions her own identity as Afrikaner and reconfigures the sense of herself and the culture she is part of. It is part of the struggle with identity and agency by the trauma patient to use repetition of metaphors, images and visualisations (like Krog) to reconstitute herself as a being of consistency, recognition and unity against the traumatic experience of the lack of agency (Ragland 13).

In the process of realisation the person integrates the traumatic experience as part of their life history. This process is an important part of this realisation and integration because "words will begin to allow the patient the forming of new semantic structures that will assist him/her to assimilate the trauma over time" (Van der Kolk 13). In Country of My Skull the use of different styles and formats reflect a variety of representational strategies that may be a reflection of different understandings of trauma (Quayson 755). The functions of these metaphors and other strategies then are not only to formulate a direct meaningful image, but rather to make itself heard in the process of seeking a language for that which is beyond speech. In Country of My Skull the different strategies include different genres, sometimes a poetic style 
and even poems, lyrical chapter headings and different voices and narrators.

The textual form of Country of My Skull that has invited so much criticism thus can be read as a case of so called "trauma realism", where moments of intense pain and suffering must be formulated which sometimes are indescribable. It is found in a textual form that includes elements of an aesthetic style that usually are thought to be anti-realistic, modernist or even postmodern in nature (Berger 578).

It seems that the techniques used in trauma fiction relate to the use of postmodern and postcolonial stylistic devices as modes of reflection and critique and that trauma fiction requires a literary form which departs from the conventional linear sequence (Whitehead 6). This also has an effect on the reader who becomes a silent witness and even emphatic listener to the telling of the traumatic event. In these texts the role of language and storytelling is foregrounded and the role of time, landscape and space will be explored to mirror at a formal level the effects of trauma (Whitehead 10, 30). It is clear that Krog uses form and style to combine her capabilities as journalist and poet to describe the traumatic events she witnesses and endures.

Garman writes about Krog's mixture and integration of journalism and poetic style when reporting on the Truth Commission on radio, articles in papers and in Country of My Skull. She also refers to the critique Krog had to endure as journalist, especially about her idiosyncratic style of reporting on the Truth Commission (198). This becomes clear when reading Krog's integration of the discussion of the events during the Truth Commission with autobiographic detail and her personal struggle to comprehend and understand issues that emerge during the process of finding words to formulate her experiences in listening to the testimonies. Garman explains that Krog has a more distanced approach in her articles in the Mail and Guardian than in the direct radio broadcasts when she uses more literary techniques. In the radio reports, says Garman, "she deals overtly with herself as the instrument of meaning-making, as discoverer of the truth" (203). It is these articles, according to Garman, that formed the basis for the construction of Country of My Skull with its similar integration of journalism (reportage), autobiography, personal experiences, verbatim testimonies and some poetry (204).

Krog said in an interview with Garman that the most difficult part of her work as journalist at the Truth Commission was "maintaining distance as a journalist; difficulty of reporting on and processing emotionally the gruesome details of atrocities; finding words to 'capture experiences' that escape description" (199). When she decides to revert to poetry, it is because she believes in conveying a very personal experience in her own special way. It is clear that Krog had to write a text wherein she could work through her own traumatic experiences and responses during the Truth Commission hearings in this process of redefining her own identity in the clash between the codes of her Afrikaner culture and the Other. She had to share the guilt about the atrocities of which she became a secondary witness with her readers 
while simultaneously formulating of new identity wherein she would be part of a new South African nation. She states emphatically: "If you cut yourself off from the process, you will wake up in a foreign country-a country that you don't know and you will never understand" (198).

\section{Recurring tropes in Country of My Skull}

Antjie Krog refers in a later article ("My heart" 226) to a victim who saw a red, growing butterfly on the blouse of his wife's upper body that fell on his lap during a massacre. She was fascinated by the use of the word "butterfly" for the fatal wound he saw. In an interview with his psychologist she was told that it took the man four years to arrive at that word and that, at that moment, he made his first step towards healing.

The title of the book already gives us the tropes to read by: The country-the variety of landscapes described in the text as a divided but seriously beloved landscape and nation; the skull as the embodied trauma and the birthplace of language, the intense sensitivity of emotion and inner thoughts (Harris; Seeley; Coetzee; Viljoen). I would like to concentrate on only four recurring and integrated themes or tropes to illustrate the use of her poetical style and the progression in perspective through the text: language, body and skull, sounds and the country or landscape. The development in perspective within these tropes also shows the process of working through the trauma towards healing.

\section{Language}

One of the most common symptoms of the experience of trauma is speechlessness, the difficulty in expressing the feelings and describing incidents that were part of the event. It is no surprise that references to language used to formulate the experiences during this struggle is one of the most recurring themes. The cry of Nomonde Calata is also proof that "pain destroys all language" and she is witness to "the destruction of language" (42). This metaphor for pain reflects Krog's struggle with and the description of the role of language in Country of My Skull.

The trauma she endures results in speechlessness: "I stammer, I freeze, I am without language" $(37,44,48)$; "my breast silts up, speechless" (48). The first poem in Country of My Skull expresses the frozen beginnings of the witness report: "dare I sit in this grape dark / my heart coagulate resigned / write I ..." (36). She also attests to the insufficiency of language to express and translate the suffering she is listening to: "There is no way you can begin to imagine the language, the rhythm, the imagery of the original stories" (238) and she fears that eventually words will not be found to heal from this history: "in the end the final trace of the word reveals a culture without mercy, unable to transmit anything but colour, a culture unable to transmit the soul. What word, what embrace will unburden us all?" (285); "What does one do with pain that does not want to become language, cannot become language?" 
(293). These "words" can be interpreted as the attempt to give language and to find language for the experiences and internal struggles she must formulate as part of developing a new identity. In this process of forming a new identity she also has to fight against her mother tongue, Afrikaans, the thoughts of betrayal as an Afrikaansspeaker/Afrikaner, but also as a writer who dares to write after so much horror and pain brought unto others. No one has, according to her, the right "to appropriate a story paid for with a lifetime of pain and destruction" (237). She could not dare to write in her mother tongue, because it is loaded with "decrowned skeletons, origins, shame and ash" (128), it is the language of the culture that must ask for amnesty (96) and she asks herself: "How do I live with the fact that all the words used to humiliate, all the orders given to kill, belonged to the words of my heart?" (238).

This is a text (and an author), says Coetzee (688), divided against itself, fighting against the language of her heart and fathers, wanting to become something else and even belonging to another race in search of a new ear, a new genealogy into which she can write herself (688). This awareness of the forming of a new identity is written in the integration of body and language: "In the beginning it was seeing, seeing for ages, filling the head with ash. No air, No tendril. Now to seeing, speaking is added and the eye plunges in the mouth. Present at the birth of the country's language itself" (29). It is in the new language that she will shed her skin according to the last poem in the text. It is through these references to language that the metaphors of a rebirth arise, which brings us to the images of the body.

\section{Embodied trauma: the metaphor of the skull and the body}

Theoretical discussions about trauma emphasize the role of the body in the experience and the processing of trauma. Karen Seeley (23) says trauma is inherently embodied, "under the skin" and in Country of My Skull it is clear that Krog uses images of the body and her reference to the skull in connection to, inter alia, language and speechlessness, the voices of different victims and witnesses, identity, landscapes, country and earth, listening to others, the metamorphosis of emotions, the progression of experience and feelings. Body parts that are frequently used as metaphors to refer to the above are especially the skull, the womb, the tongue, throat, breast, heart, face and skin.

The title of the text already combines body, skull and landscape. The country of my skull: the country within the skull, all the skulls, bones, bodies in the country. The title refers to the interconnectedness of country and author, the country as inner landscape, all the associations with death and burial and the excavation of the horrors of the past. But there is also a part of her that refers to her vulnerability, her fragmented self that must still be reintegrated: "the surge of language by its soft, bare skull". The vulnerability may also refer to the intense violation and invasion of the images and witnessing of horror and violence that she experiences and must capture 
in stories and translation. Part of this identity is the skull as her physical being where the country is an internal creation, imagination, or even memory (Coetzee 685).

It is not without reason that Country of My Skull starts with the image of womb and rebirth although other images of parts of the body are used quite frequently: language is often referred to as "tongue" $(27,90)$, the language must also be seized by its "soft, bare skull" (27) but the experiences "fight my tongue" (27) and "strips my tongue" (86) and her "tongue goes thick" (90). She describes the birth of a new language as developing from sight, and eventually to speaking when, "the eye plunges in the mouth" (29). She becomes "exhausted because of language" (37). She feels that "pain destroys language" (42). When she freezes in speech her "breast silts up" (48) and her heart begins to "coagulate" (36).

When a rash develops on her face, as a symptom of the traumatic experiences, she refers to her "evil human face" (97) that also alludes to the horrors she is witnessing (Coetzee 693). The horror of the past is described in the reference to the Eastern Cape as "a scalp of green silence" (33) and "the arteries of the past bleed their own rhythm" (37). Krog refers to the heart as intensely connected to the country, the soil and the earth and later comes to the conclusion that her heart must become black to really be part of this country (239). She also uses this image to refer to the core of her emotions in experiencing the terrors of the past: "wrenching the heart out of horror" (88).

In all the time spent as a secondary witness, the ear is seen as a symbol of listening to the other, being witness, the organ that must first open up to become part of this experience, is first described as "the frigid earhole of stone" (56) that has no option but to be forced open by the voices of all the victims. According to Coetzee (693) the metaphor of the ear also refers to a past where people's ears were closed to the pain of others and their tongues (voices).

One of the most important bodily parts Krog refers to is the skin. The skin is seen as part of her identity, as part of the conflict between races, part of the image of violence done to others, as something that must change (figuratively but also in reality) to become part of a new dispensation after the Truth Commission.

When she closes her memoir-reportage in the final poem, it is all about the bodythe Other must be experienced within and as part of her own body, to work through and integrate all the trauma of the past in a new agency. In this poem all the various elements of the body are included and integrated in an image of a metamorphosis that she wishes to take place: skull, country, skin, heart, tongue, and ear.

Krog combines the body with her experience of the inefficiency of the language and images that must change. The word must eventually journey through skin to become the "skinned word" (285), she names the last chapter at the end of her work in the Truth Commission "Down to my last skin" (257) and wishes to become scorched to a "new skin" which includes all the associations of race and colour as dominant factors in the South African history and her personal experiences (Coetzee 693, 694). 
As Wilkinson (242) describes it: "The body is the theatre [...] the body speaks [...] the body remembers $[\ldots]$ and the body keeps the score..."

\section{Sounds}

Country of My Skull is filled with the sounds of different voices, sounds of violence, sounds of radio reports, sounds of oral testimonies, electronic devices, songs, the sounds of silence that refer to the oppression of voices, the secrecy of operations but also the silence of a peaceful, united country. Garman (189) names Krog's close attention to sound as one of the characteristics of her poetry into journalism in Country of My Skull. Taiwo Osinubi (2008) specifically discusses the use of sounds as metaphor in Country of My Skull. The role of listening and the ear in her experiences as secondary witness to the testimonies of trauma also plays an important part. The aspect of sound integrates on a literary and figurative level with the trope of bodily experiences of the traumatic events.

Osinubi begins his discussion with a general overview of the nature and style of Country of My Skull as representative of the effort of the author to find a form for the discussion of the workings of the Truth Commission and the experience of the witnesses and testimonies (109-10). He draws attention to the fact that the overdetermination of certain elements, like sounds, is a direct indication that the text must not be read as an objective, realistic report. He interprets the direct testimonies that are quoted with or without names, as representative, paradigmatic of a huge number of other testimonies and events that were not or could not also be included.

Krog starts her narrative with the juxtaposition of the description of the roar of the Sierras of the Afrikaner Weerstandsbeweging (AWB) against the holy silence with the naming of all the victims of police brutality "that chimes into silence" (1). The harsh sound of the marching Ystergarde's boots is followed by: "you can hear an alliteration drop" (1). On this first page the description and her experience of sound is already used to create an atmosphere of division and contrast of different worlds: the past of violence and pain versus the world of silenced violence and injustice, as well as the enormity of the horror people had to endure.

On the one hand the text/testimonies are characterized by silences; on the other hand, there are the continuous sounds of violence: shouts, shrieks, guns firing, explosions, a deafening noise. In this way sounds have an immediacy and realism that emphasizes the effect of what she is witnessing and the inescapability of the experience on the reporters, translators and journalists: "the first narrative cut into the country, penetrating even the most frigid earhole of stone" (56).

Osinubi even sees the references and explanations of the working of the media at the Truth Commission as one of Krog's metaphorical techniques to represent the experiences and violence that are in a certain sense "intransmittable" (114). Krog also uses the "electronic transmission" as an instrument to render a realistic experience 
figuratively to add an emotional and sensory experience (116). As an example Osinubi discusses the description of the sounds of the radio at the time of a robbery on their farm (Country 7). According to Osinubi the emphasis on sound effects, because it has such an effect of immediacy, are important throughout the text because it engages the reader with the events.

Krog uses these contrasting sound environments to suggest the underlying violent atmosphere. There are the references to shouting, loud noises versus silences, the titles of chapters, the sound atmosphere in and around places, the reference to sounds in direct testimonies, the reconstruction of sound in the atmosphere of events, the cumulative effect of violence and the contrasting vulnerability of victims that are created in this manner (Osinubi 119-20).

The direct reference to a variety of silences are quite conspicuous and have different implications. The silences implicate the unnameable experience of trauma, the unheard voices of all the women that were raped and an era of violence that was never talked about ("the tyranny of silence"). Eventually it points to a backdrop of silence against which the events are narrated now for the first time.

\section{Landscapes}

The experience of a space and world full of sound is integrated with the experience and description of the landscape. In the beginning of the text the Eastern Cape is described as covered in a "speechless darkness" (34). Krog mentions a new space and landscape that must be created where not only the violence of the past, but also the present with its openness and the exposure of justice and the town hall can be seen as belonging to all the inhabitants (35). The silence of mountains that lies in such heavenly peace is contrasted with the evidence of violence in the silence after the explosion of a land mine (48). The landscape becomes the image of the struggle between the powerful and powerless, a landscape full of misunderstandings (88). Queenstown, with its green grass-covered mountains keeps the terrible silenced secret of the most gruesome history of necklacings (134), Table Mountain that was covered in the morning with the most beautiful blue sky, is silent and "in shock and sorrow" (152) after the news of Archbishop Tutu's cancer. In Louis Trichardt the bitter cries and broken words of victims are interrupted by the applause of an enthusiastic cricket crowd on the field nearby (195).

Gradually she becomes aware of the price that had to be paid for the safety of her family home on the farm, "the most beloved state of heart" (272) and she herself is silenced because she has no more words for this experience (278).

In the final words of identification with this country, the country of her skull, it is formulated with reference to sound: "I would die for this. It slips out, like a smooth holy sound. And I realize that this is the commission alone that has brought me to these moments of fierce belonging" (363). 
Whitehead $(50,51)$ states that in trauma narratives our readings are always combined with "inherited memory, factual information and personal and national politics [...] invested with traces of longing and belonging [...] part of a symbolic topography". The use of landscape as metaphor is, according to her, one way in which the narrator can bring into symbolic language the expression of the inexplicable experiences, creating the interior spaces in which grief can emerge (77). Viljoen (78-81) writes that Krog is part of the Afrikaans literary tradition in which space and landscape is one of the most important themes. According to her that is why Krog is enabled to use landscape as a source of identity through the description of her experiences of the Truth Commission by the revisiting of landscape, places and the country which were part of her life all along. Krog was placed in a position to place herself in a new perspective to look through the eyes of the Other at the familiar landscapes. In that process she was able to include the other voices of this country and also their perspective on the country. This is one of the reasons why one of the characteristics of Country of My Skull is the emphasis on detailed descriptions of places and landscapes in this very personal report. Evidently Krog's writing of landscapes is loaded with cultural and historical codes as well as the contrasts between beautiful descriptions of landscape and the horrors that took place there.

Krog's title, Country of My Skull, indicates the intensity of feeling and identification with this country. At the start of this text the safe environment of the farm is described as a womb into which she can crawl (4). But she emphasizes the contrasts and complexities in identifying with this landscape. She also starts with a description of sorrow: a "web of infinite sorrow [...] A wide, barren, disconsolate landscape..." (32) Even while listening to the most terrible horrors she still paradoxically claws at the beauty of her home ground, the Free State: "landscape of paradise and a language from paradise: mispel, maroela, tarentaal..." (48). She admits that this same landscape is one of power struggle and filled with misunderstanding (88) so that she hears "a thin song, hooves, hedges, venom, fever and destruction fermenting and hissing underwater" (130).

She also realizes that she is bound to this country and soil. She agrees with her mother that "land is the essence of the Afrikaner" (273) of which she is part. She still engages and identifies strongly with the beauty of the Free State landscape: "This is my landscape. The marrow of my bones [...] The blond-honey sandstone. This I love", but then it should be in unison with the other inhabitants of this country: "in the voices, all the voices of the land" (210).

This landscape is one of contrasts, the country silent without a unified language of understanding and empathy. The farm, her home ground, is "desperately beautiful" and her nostrils there filled "with the blessed smell of wet earth and stone" $(272,273)$. But although this was the place that once "first wakened [her] for words" (273) it is no longer the case: because this safest place she knew "has turned into an 
island under threat" (273). Part of her new perspective on this land is the perspective that this country, even their specific farm, should be part of a bigger, shared space, full of other voices also: "this is the place that first wakened me for words and still does-after all these years, these many other voices" (272). I agree with Viljoen that part of Krog's healing process after the traumatic experience of the Truth Commission is that she could find other words to describe her relationship with the well-known and beloved spaces/landscapes (89).

Krog is also describing a new landscape that becomes representative of the landscape of the Afrikaner identity versus the other, more resonant and at the same time safe space that, according to Krog, developed as a result of the events of the Truth Commission. She quotes the example of the experience at Ladybrand when the crowd starts singing the new national anthem in Sotho: "And I wade into song-in a language that is not mine, in a tongue I do not know. It is fragrant inside the song, and among the keynotes of sorrow and suffering there are soft silences where we who belong to this landscape, all of us, can come to rest [...] Sometimes the times we live in overflow with light" (217). The same experience of landscape is described at the end of Country of My Skull in her final reflection on the Truth Commission: "painstakingly it has chiselled a way beyond racism and made space for all our voices" (278).

Krog wonders if there is space for all the people of this country (258) and comes to the belief that she belongs to the "black heart" of this country. Only then can the country also be "truly mine" (259). So she refers to the "Country of Grief and Grace" (261) but when she returns from Robben Island to Cape Town with the Commission she can conclude: "I would die for this country. It slips out like a smooth, holy sound [...] these moments of fierce belonging" (277). The offering she would bring to a memorial for all the victims of the past will be the soil of her home ground: "soft-rose coloured sandstone from the place I was born" (288). The perspective on the landscape of the title, the Country of My Skull, is broadened to a new spacious identity, a wider imagined meaning, a sign that the metaphor of country and land has been opened to a new insight, and is also a sign of healing (Viljoen 91). The last poem in Country of My Skull then refers metaphorically to a new country that is forming in her thoughts and words, showing the way to other and new relations between the people of this country.

\section{Conclusion}

Although some critics have referred to the tropes and images of language, body and skull, sounds and landscape or country as those of an "overtly fictionalized personal landscape" (Moss 88; Cook 75), I read it as part of a highly personal and sometimes lyrical/poetical description to give words to an experience which escapes a "normal" formulation. Therefore the personal, fictionalized and poetical language is part of a trauma narrative describing the traumatic experience and the state of mind of the 
narrator in the process of working through the trauma. Krog's text is evidence of her struggle to find a form in which to recontextualize and restructure a fragmented identity in relation to previous beliefs, loyalties and perspectives.

The parts of lyrical, poetic language with its poems and recurring images or tropes are evidence of the state of the narrator-author-witness in a process of reintegration and transference through the trauma narrative. The signs of development in different perspectives on country, language, body and sound(s) show the process of healing and changing identity and agency, what Van der Hart and Brown (15) call "the conciliation between [...] the narrative of the trauma and the personality of the subject". During this stage of integration and realization new meaning structures are developed. Wilkinson (490) refers to this stage as the revisiting and reworking towards a coherent narrative, the way of finding a framework of symbolic images and semantic structures that help assimilate the trauma as part of the process of realization and integration.

The discussion of different tropes shows the development from static images and perspectives to the opening of new perspectives. From the viewpoint of trauma theory and the importance of the metaphorical processes in the experience and memory of trauma, it is clear that the integration of the bodily experience, the struggle to find language to express this and the emotions and contexts associated with that experience lead to a transference from the unexplained and indescribable to an expression that can be formulated in language.

The different references to language begin with an emphasis on speechlessness, the destruction of language, a mother tongue that only indicated violence and inhuman behaviour and syllables that vibrate with sorrow. Later it changes to the mentioning of a new language being born and found, a new tongue that is "ignited" and harsh sounds that are changed to "soft intimate clicks and gutturals".

The images associated with the body develop from a skull, a scalp of green silence, the "frigid earhole of stone", to a new womb, listening to all the voices of this land. The skin that was always the symbol of racism and hatred, the source of violence and killing, became a "new skin". The sounds of silence and noises that indicated violence, secrets, horror and terror became the sound of all the voices of this country, and the final identification with this country comes out as a "soft, holy sound".

Krog (Country 278, 279) integrates all these thoughts and the metaphors in the final poem in the text. The description of landscapes of horror opens up to a bigger, more open space where there must be place for all, so that "this country no longer lies between us / but within". The beloved soil of her family farm and the Free State becomes the land inhabited by all, the country "breathes becalmed". After she was "scorched" by a thousand stories she is "changed forever". In Country of My Skull, the narrator has to go back to the beginning of language to discover a new language. Not only are the ambiguous, open meanings of the images and descriptions of body, skull, 
landscape and country, language, senses, sounds, betrayal, race, conflict and trauma brought together, but also concludes in a final decision and insight that opened up after the metaphorical working through of a traumatic experience.

\section{Works Cited}

Anker, J. "Metaphors of pain: the use of metaphors in trauma narrative with reference to Fugitive Pieces." Literator 30.2 (2009): 49-68.

Berger, J. “Trauma without disability, Disability without trauma: A disciplinary divide." Jac 24.3 (2004): 563-82.

. "Falling Towers and Wild Children: Oliver Sacks, Don DeLillo, and Turns against Language." PMLA 120.2 (2005): 341-61.

Botha, M. "Traumaverwerking in Krog se Kleur kom nooit alleen nie." Tydskrif vir Geesteswetenskappe 54.3 (2014): 524-41.

Borbelly, A. F. "Psychoanalytic concept of metaphor." The International Journal Of Psychoanalysis 79 (1998): 923-36.

Brevin, C. R. Post-traumatic stress disorder. Michigan: Vail-Ballou, 2003.

Caruth, C. Unclaimed Experience: Trauma, Narrative and History. Baltimore: Johns Hopkins U P, 1996.

Coetzee, C. "'They never wept, the men of my race': Antjie Krog's Country of My Skull and the White South African signature." Journal of Southern African Studies 27.4 (2001): 685-96.

Connoly, A. "To speak in tongues: language, diversity and psychoanalysis." Journal of Analytical Psychology 47 (2002): 359-82.

Cook, M. “Metaphors for suffering: Antjie Krog's Country of My Skull.” Mosaic 14.3 (2001): 73-89.

Coullie, J. "Remembering to forget: Testimony, collective memory and the genesis of the 'new' South African nation in Country of My Skull." Current Writing 19.2 (2007): 123-43.

Coullie, J. L. and A. Visagie, eds. Antjie Krog: An Ethics of Body and Otherness. Pietermaritzburg: UKZN P, 2014.

Garman, A. "Running with the jackals: Antjie Krog the journalist." Antjie Krog: An Ethics of Body and Otherness. Eds. Judith Lütge Coullie and Andries Visagie. Pietermaritzburg: UKZN P, 2014. 184-214.

Graham, S. "The Truth Commission and post-apartheid literature in South Africa." Research in African Literatures 34.1 (2003): 11-30.

Harris, A. "Accountability, acknowledgement and the ethics of quilting in Antjie Krog's Country of My Skull." Journal of Literary Studies 22.1/2 (2006): 27-53.

Kaminer, D. "Healing processes in trauma narratives: a review." South African Journal of Psychology 36.3 (2006): 481-99.

Krog, A. Country of My Skull. Cape Town: Random House Struik, 2009 [1998].

. "Last time, this time." LitNet. 20 March 2006. 24 April 2014. < http://www.oulitnet.co.za/seminarroom/krog_krog2.asp >.

. "Overwhelming trauma of the truth". Mail \& Guardian 9 Jan. 1997: 10.

Lakoff, G. and M. Johnson. Metaphors We Live By. Chicago: Chicago U P, 2003 [1980].

Modell, A. H. "Emotional memory, metaphor, and meaning." Psychoanalytical Inquiry 25 (2003): 555-68.

Moss, L. "Nice audible crying': Editions, testimonies and Country of My Skull." Research in African Literatures 37.4 (2006): 85-104.

Olivier, B. "Trauma and Literature: Derrida, 9/11 and Hart's The Reconstructionist". Journal of Literary Studies 24.1 (2008): 32-57.

Osinubi, T. "Abusive narratives: Antjie Krog, Rian Malan and the transmission of violence." Comparative Studies of South Asia, Africa and the Middle East 28.1 (2008): 109-21.

Peres, J., Mercante, J. and G. Nasello. "Psychological dynamics affecting traumatic memories: implications in psychotherapy." Psychology and Psychotherapy: Theory, Research and Practice 78 (2005): 431-47.

Quayson, A. "Symbolization Compulsion: testing a Psychoanalytical category on Postcolonial African Literature." University of Toronto Quarterle, 73.2 (2004): 754-772.

Ragland-Sullivan, E. “The physical nature of trauma: Freud's Dora: the young homosexual woman, and the Fort! Da! Paradigm." Postmodern Culture. Journal of Interdisciplinary thought on Contemporary Cultures 11.2 (2001). 23 Apr 2014. DOI: 10.1353/pmc.2001.0003 < http://muse.jhu.edu/article/27731>.

Rostan, K. "The ethics of infidelity in Country of My Skull." Eds. Judith Coullie and Andries Visagie. Antjie 
Krog: An Ethics of Body and Otherness. Pietermaritzburg: UKZN P 2014. 24-43.

Schwager, E. "Transforming dualism and the metaphor of terror. Part 1: From genocidal to dialogic mentality: an intergenerational struggle." Psychoanalytic Review 91.3 (2004): 347-94.

Seeley, K. "Trauma as metaphor: the politics of psychotherapy after September 11." Psychotherapy and Politics International 3.1(2005): 17-27.

Speary, S. "Displacement, dispossession and conciliation: the politics and poetics of homecoming in Antjie Krog's Country of My Skull." Scrutiny 2: Issues in English Studies in South Africa 5.1 (2000): 64-77.

Van der Hart, O, K. Steele and P. Brown. "The treatment of traumatic memories, realization \& integration." Dissociation 6.2/3 (1993): 162-80.

Van der Kolk, B. A. "Posttraumatic therapy in the age of neuroscience." Psychoanalytical Dialogues 12.3 (2002): 381-92.

Van der Merwe, C. and G. Goboda-Madikezela. Narrating our Healing: Perspectives on Working through Trauma. Newcastle: Cambridge Scholars Press, 2007.

Viljoen, L. Ons ongehoorde soort. Beskouings oor die werk van Antjie Krog. Stellenbosch: Sun Press, 2009.

Walker, G. and E. Unterhalter. "Knowledge, narrative and national reconciliation: Stories, reflections on the South African Truth and Reconciliation Commission." Discourse: Studies in The Cultural Politics of Education 25.2 (2004): 279-97.

Wallmach, K. "'Seizing the surge of language by its soft, bare skull': Simultaneous interpreting of the Truth Commission and Country of My Skull." Current Writing 14.2 (2002): 64-82.

Whitehead, A. Trauma Fiction. Edinburgh: Edinburgh U P, 2004.

Wilkinson, M. "Undoing trauma: contemporary neuroscience." Journal of Analytical Psychology 48 (2003): $235-53$.

. "Undoing dissociation: affective neuroscience: a contemporary Jungian clinical perspective." Journal of Analytical Psychology 50 (2005): 483-501.

Williams, W. I. "Complex trauma: approaches to theory and treatment." Journal of Loss and Trauma, 11 (2006): 321-35. 